\title{
PENGARUH EKSPOR DAN IMPOR MINYAK MENTAH TERHADAP CADANGAN DEVISA DI INDONESIA TAHUN 1996-2018
}

\author{
Siska monita ${ }^{*}$, Devi Andriyani ${ }^{* b}$ \\ *Fakultas Ekonomi dan Bisnis Universitas Malikussaleh \\ a Corresponding author: deviandriyani@unimal.ac.id \\ b $\underline{\text { Siskamonita406@gmail.com }}$
}

\section{A R T I C L E I N F O R M A T I O NA B S T RA C T}

\section{Keywords:}

Crude Oil Exports, Crude Oil

Imports, Foreign Exchange

Reserves.
This study aims to analyze the effect of exports and imports of crude oil on foreign exchange reserves in Indonesia from 1996 to 2018. This study uses secondary data and multiple linear regression to analyze the data. The results partially show that crude oil exports have a negative and significant effect on foreign exchange reserves, and Crude oil imports have a positive and significant effect on the foreign exchange reserve. Simultaneously, exports of crude oil and imports of crude oil have a positive and significant effect on foreign exchange reserves in Indonesia. The amount of influence is 0.7661 or $76.61 \%$, while the rest is influenced by other variables outside the model of 23.39\%. Bank Indonesia should maintain the balance of foreign exchange reserves, and the Government can provide policies to the public, especially those who are going to the export to find it easier to fulfill the requirements and must suppress imports growth.

\section{PENDAHULUAN}

Menurut (Soi et al., 2013), perdagangan memberikan peluang baru untuk pertumbuhan bagi negara-negara berkembang, karena setiap negara pasti akan melakukan perdagangan antar negara untuk mencukupi kebutuhan dan mensejahterakan masyarakatnya. Dengan adanya kegiatan tersebut maka negara - negara di dunia dapat melakukan pertukaran sumber daya milik masing-masing negara.

Cadangan devisa adalah sebuah alat ukur moneter yang dibutuhkan untuk melihat kuat atau lemahnya pertahanan ekonomi suatu negara. Selain itu total devisa yang tinggi juga menjadi jaminan terwujudnya stabilitas moneter dan perekonomian makroekonomi di negara (Tambunan T, 2001)

Cadangan devisa memiliki peran yang penting untuk posisi nilai tukar suatu negara. Semakin banyak devisa yang dimiliki oleh pemerintah dan penduduk suatu negara maka makin besar kemampuan negara tersebut melakukan kegiatan ekonomi hingga makin kuat pula nilai mata uang. Jadi semakin tinggi ekspor dan nilai tukar mata uang negara, memperlihatkan bahwa makin kuatnya perekonomian suatu negara, hingga dapat meningkatkan cadangan devisa( Andriyani, mustafa 2020).

Bank Indonesia selaku pemegang devisa negara, dalam pengelolaanya boleh melaksanakan semua kegitan yang berkaitan dengan sumber devisa, misalnya pinjaman luar negeri, ekspor, impor, atau nilai tukar karena kesemua itu memliki pengaruh bagi peningkatan devisa (Uli, 2016). Cadangan devisa bisa dipakai sebagai indikator utama untuk melihat sejauh mana suatu negara melakukan perdagangan internasional untuk meningkatkan perekonomiannya. Mengingat betapa pentingnya cadangan devisa bagi suatu negara maka kegunaan kondisi cadangan devisa harus diperlihara, agar semua transaksi dalam perdagangan internasional dapat berjalan lancar atau stabil.

Salah satu langkah yang dilakukan pemerintah untuk mendapatkan devisa yaitu dengan menjual atau ekspror hasil produksi negeri, lalu hasilnya akan dipakai memperbaiki pembangunan dalam negeri (Ridho, 2015). 
(Amir, 2004) menyebutkan bahwa ekspor merupakan kegiatan penting pada penjualan internasional, dimana ekspor adalah kegiatan menjual barang keluar negri dengan menggunakan pembayaran, kualitas, kuantitas dan syarat penjualan lainnya dengan adanya persetujuan dari pihak penjual dan pembeli.

Selain kegiatan ekspor, aktivitas dari kegiatan impor juga berdampak terhadap perekonomian suatu negara dan masyarakat. Kegiatan impor adalah upaya seorang pengusaha untuk mencukupi keperluan industry terhadap barang yang tidak ada didalam negeri, sehingga terpaksa membelinya dari negara lain. Di satu sisi impor yang tinggi baik untuk negara karena dapat menyediakan kebutuhan masyarakat negara tersebut seperti produk atau jasa, namun sisi lainnya bisa mematikan produk dan jasa sejenis dalam negeri, dan yang paling mendasar menguras devisa negara tersebut (Amir, 2008)

Menurut (Ekanada, 2014), untuk menjaga produsen dalam negeri yang lemah akan produksinya maka suatu negara akan mengurangi tingkat impor. Selain itu, pembatasan impor juga mempunyai dampak besar bagi peningkatan ekonomi negara. Menurut (Prambudia, 2012) produksi minyak Indonesia terus menerus merosot tajam dalam kurun waktu 10 tahun belakang. Pada tahun 2000 terjadi pengurangan antar jumlah produksi dengan total minyak yang dikonsumsi sehingga indonesia keluar dari keanggotaan Asia Pacific Economic Cooperation (APEC). Tahun 2008 akibat trend produksi minyak mentah yang semakin merosot sedangkan trend konsumsi minyak mentah semakin meningkat (Atty et al., 2013). Secara alami penyebab turunnya produksi minyak mentah Indonesia karena kondisi cadangan minyak yang sudah menipis sehingga tidak memungkinkan lagi untuk dilakukan eksploitasi. Berikut perkembangan ekspor, impor minyak mentah dan cadangan devisa di Indonesia

Tabel 1.1 Perkembangan Ekspor, Impor Minyak Mentah dan Cadangan Devisa Tahun 2013-2018

\begin{tabular}{|c|r|r|r|}
\hline Tahun & $\begin{array}{c}\text { Ekspor Minyak } \\
\text { Mentah } \\
\text { (Juta US\$) }\end{array}$ & $\begin{array}{c}\text { Impor Minyak } \\
\text { Mentah } \\
\text { (Juta US\$) }\end{array}$ & $\begin{array}{c}\text { Cadangan Devisa } \\
\text { Indonesia } \\
\text { (Milyar US\$) }\end{array}$ \\
\hline 2013 & $10.204,7$ & 13.585 .8 & 96.364 \\
\hline 2014 & 9.251 & $13.072,4$ & 108.836 \\
\hline 2015 & $6.479,4$ & $8.063,3$ & 103.268 \\
\hline 2016 & $5.196,7$ & $6.730,5$ & 113.493 \\
\hline 2017 & $5.354,9$ & $7.063,6$ & 113.922 \\
\hline 2018 & 5.645 & 8.576 & 109.131 \\
\hline
\end{tabular}

Sumber: Badan Pusat Statistik \& Islamic Development Bank 2018
Berdasarkan tabel 1.1 dapat kita perhatikan bahwa ekspor dan impor minyak mentah dan cadangan devisa bersifat fluktuatif. Dapat diperhatikan bahwa perkembangan ekspor minyak mentah pada tahun 2013 sebesar US\$ 10.204,7 juta kemudian ditahun 2014 mengalami penurunan menjadi sebesar U\$S 9.251 juta. Kembali mengalami peningkatan pada ekspor minyak mentah menjadi sebesar US\$ menjadi sebesar US\$ $6.279,4$ juta ditahun 2015, di tahun 2016 menurun kembali menjadi sebesar US\$ 5.19,7 juta, namun tahun 2017 meningkat menjadi sebesar US\$ 5.354,9 dan tahun 2018 sebesar US\$ 5.645 juta. 41.318 milyar. Sama halnya dengan negara Brazil yang tidak tertinggal dengan cadangan devisa yang cukup tinggi tercatat sebesar US\$ 125.686 Milyar.

Namun jika dikaitkan dengan cadangan devisa, pada tahun 2014 ketika ekspor mengalami penurunan menjadi US\$9.251 juta, di sisi cadangan devisa mengalami perkembangan kenaikan menjadi sebesar US\$ 108.836 milyar. Hal ini tidak sesuai dengan teori yang dikemukakan oleh (Ridho, 2015) yang menyatakan apabila ekspor disuatu negara menurun maka cadangan devisa yang dimiliki negara bersangkutan akan menurun, dan begitu pula dengan sebaliknya.

Kemudian perkembangan ekspor minyak mentah juga mengalami penurunan pada tahun 2016 sebsar US\$ 5.196,7 juta tetapi cadangan devisa berkembag kearah yang lebih baik yaitu mengalami peningkatan menjadi sebesar US\$ 113.493 milyar. Hal ini tentu tidak sesuai dengan teori yang dinyatakan oleh (Wahyuni, 2011) yang menyatakan bahwa apabila ekpsor menurun maka cadangan devisa juga akan menurun dan apabila ekspor meningkat maka cadangan devisa juga akan meningkat.

Perkembangan impor minyak mentah selama 6 tahun terakhir juga terus mengalami fluktuasi, dimana pada tahun 2013 impor minyak mentah tercatat sebanyak US\$ $13.585,8$ juta, kemudian terus mengalami penurun hingga di tahun 2016 menjadi sebesar US\$ $6.730,5$ juta, sedangkan cadangan devisa terus mengalami peningkatan.

Namun ditahun 2017 perkembangan impor minyak mentah kembali meningkat menjadi US\$ 7.063,6 juta tetapi cadangan devisa juga meningkat sebesar US\$ 113.922 milyar hal ini juga tidak sesuai dengan teori yang di kemukakan oleh (Benny, 2013) yang menyatakan bahwa semakin tinggi nilai impor maka akan mengurangi cadangan persedian cadangan devisa yang ada di suatu negara. Menipisnya cadangan devisa dapat menyebabkan menumpuknya tagihan pembayaran terhadap barang impor dan ini tentu akan 
menurunkan kredibilitas negara di mata internasional, efeknya eksportir luar negeri tidak mau menjalin kerjasama dengan importir dalam negeri.

Penelitian ini bertujuan untuk mengetahui seberapa besar pengaruh eksor minyak mentah, impor minyak mentah terhadap cadangan devisa Indonesia. Beberapa penelitian terdahulu yang menyatakan adanya hubungan antara ekspor dan impor dengan cadangan devisa diantaranya penelitian (A. P. Sonia \& Setiawina, 2016), (Benny, 2013), (Agustina, 2014), (Sabtiadi \& Kartikasari, 2018) dan (Dewi \& Sudirman, 2015) yang menyebutkan bahwa ekspor dan impor minyak mentah mempunyai pengaruh terhadap cadangan devisa di indonesia.

Pembahasan kedua dari penelitian ini akan mengkaji tetang tinjauan teoritis, lalu pada bagian ketiga akan dibahas metode penelitian, pada bagian keempat akan dibahas hasil dan penelitian, bagian kelima atau terakhir akan dibahas kesimpulan dan saran.

\section{TINJAUAN TEORITIS}

\section{Cadangan Devisa}

Cadangan devisa adalah salah satu sumber pembiayaan yang mempunyai peran penting dalam perdagangan internasional. Pasal No. 13 Undang-Undang Indonesia menyebutkan bahwa tugas BI dalam mengelola cadangan devisa berupa emas, uang kertas asing, dan tagihan lainnya digunakan sebagai alat pembayaran luar negeri. Selain itu, cadangan devisa dipakai untuk traksaksi ekspor dan impor, membayar hutang negara, dan intervensi di pasar valas guna menstabilkan nilai tukar (Leonufna et al., 2016).

Cadangan devisa bisa didapat dari kegiatan penjualan antar negara (Juniantara \& Sri Budhi, 2012). Untuk Indonesia, pembiayaan impor dan pembayaran utang merupakan fungsi utama dari cadangan devisa. Hal ini karena mata uang rupiah tidak dapat diterima secara global sehingga dalam transaksi internasional pemerintah menggunakan mata uang internasional yaitu dolar AS

(Reny \& Agustina, 2014) mengemukakan bahwa, cadangan devisa menjadi salah satu faktor utama yang dapakai oleh berbagai negara manapun dalam menentukan kuat lemahnya fundamental perekonomian suatu negara. Indonesia termasuk negara yang sedikit memiliki ketersediaan pada cadangan devisa sehingga mengakibatkan tidak sanggup untuk menjaga keseimbangan nilai tukar dan melakukan pembayaran ketika mengalami terjadi defisit neraca pembayaran serta anjloknya nilai tukar rupiah. Ketersediaan devisa memegang posisi penting dalam transaksi impor.

Alasan kegiatan impor yang dilakukan suatu negara yaitu, karena tidak cukupnya produksi dalam negeri untuk mencukupi kebutuhan sendiri atau bahkan negara tersebut tidak dapat memproduksinya sendiri.

\section{Ekspor}

kegiatan menjualkan hasil produk negara kepada negara lain dengan melewati batas wilayah kepabeanan, serta bertujuan agar mendapat devisa yang sangat diperlukan negara, membuka lapangan kerja untuk pasar tenaga kerja domestik, juga memperoleh pemasukan bea keluar dan pajak lainnya, menjaga keseimbangan antara arus barang dan arus uang beredar di dalam negeri dinamakan ekspor. (Sasono, 2013).

Peranan ekspor adalah sebagai alat pendorong pertumbuhanekonomi negara dengan meningkatkan devisa negara. Ketika tingkat ekspor melemah maka cadangan devisa akan mengalami penurunan dan sebaliknya jika tingkat ekspor tinggi maka cadangan devisa yang dimiliki juga akan meningkat (A. Sonia \& Setiawina, 2016)

Menurut teori keunggulan mutlak yang dijelaskan oleh Adam Smith, ia mengemukakan bahwa negara akan makmur apabila mampu mengembangkan produksnya dari perdagangan. Agar produksinya meningkat perlu adanya penjualan luar negeri,seperti ekspor dan impor. Menurutnya ekspor adalah hal yang positif untuk meningkatkan kesejahtraan masyarakat melalui penigkatan pendapatan. Sedangkan impor akan mencukupi keperlan yang tidak dapat diciptakan dalam negeri. Tidak selamanya ekspor berjalan dalam keadaan stabil, dalam pelaksanaanya akan terdapat hambatan yang akan dihadapi, masalahmasalah ini terbagi menjadi dua kelompok utama yaitu masalah internall dan ekstrnal (Feriyanto, 2015).

\section{Impor}

Suatu proses pembelian braang dari negara lain secara resmi kedalam neggara sendiri. Tahapan ini seperti memasukan barang atau komodiitas dari negara lain pada negeri sendiri. Impor barang dalam jumah bayak memerlukan campur tangan pihak Pengelola beacukai dimasing-masing negara bersangkutan. Produk impor yaitu barangbarang yang tidak mampu diproduksi atau sudah dapat dihasilkan, namun tidak cukup untuk mencukupi keperluan rakyat. (Benny, 2013)

Dalam statistik perdagangan internasional impor dikatakan mempunyai sifat berbanding terbllik dengan ekspor. Permintaan untuk pmbelian 
barang impor tergantung pada harga relatif suatu barang luar negeri dan dalam negeri. Oleh sebab itu volume impor akan di pengaruhi oleh ouput dalam negri dan harga relative antar barang. Impor ditentukan oleh kesanggupan menghasilakan produk yang dapat bersaing dengan buatan negara lain. Yang berarti nilai impor tergantung pada pendpatan nasional negara tersebut. Makin tinggi nya tingkat impor maka pendapatan nasional nya juga akan semakin tinggi. (Mustika et al., 2015)

Menurut (Sukirno, 2005) impor suatu negara ditentukan oleh sebab tinggi daya saing negara lain proteksi penjualan dilaksanakan negara dengan mengumpulkan kurs atau valuta asing. Penentu impor utama adalah pendapatan masyarakat suatu negara, semakin tinggi pendapatan masyarakat, maka semakin banyak impor yang dilakukan.

Besarnya impor yang dilakukan oleh suatu negara antara lain ditentukan sampai dimana kesanggupan barang yang di produksikan di negara lain untuk bersaing dengan barang yang dihasilkan di negara itu. Apabila barang di luar negeri kualitasnya lebih baik atau harganya yang murah dari pada barang yang sama dihasilkan di dalam negeri maka adanya kemungkinan bahwa negara itu akan mengimpor lebih banyak.

\section{Kerangka Konseptual}

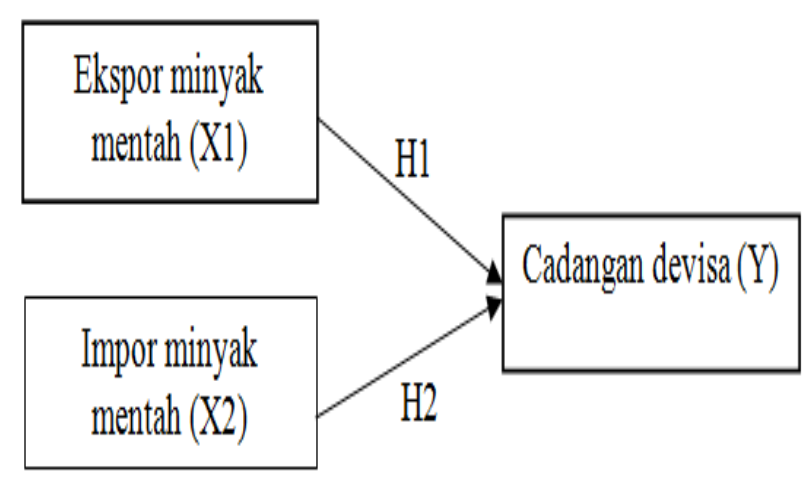

Gambar 2.1

Kerangka Konseptual

Kerangka konseptual pada gambar 2.1 di atas menjelaskan untuk melihat seberapa besar pengaruh eskpor minyak mentah dan impor minyak mentah yang akan di ukur dengan menggunakan metode Regresi Linear Berganda. adalah :

Adapun hipotesis alternatif yang dipakai

H1: Diduga eksporminyak mentah berpngaruh terhadap cadangan devisa di Indonesia tahun 1996-2018.

H2: Diduga impor minyak berpengaruh terhadap cadangan dvisa di Indonesia tahun 19962018.

\section{METODEPENELITIAN}

\section{Objek dan Lokasi Penelitian}

Objek dalam penelitian adalah ekspor, impor minyak mentah dan cadangan devisa. Adapun pemilihan lokasi penelitian yang digunakan adalah negara Indonesia.

\section{Teknik Pengumpulan Data}

Metode pengumpulan data dilakukan melalui studi pustaka, internet, BPS, serta ISDB. Studi pustaka dilakukan dengan mempelajari sumber yang berisian informasi berhubungan dengan pembahasan yang sedang diteliti dengan tema penelitian. Data ekspor, impor minyak mentah dan cadangan devisa diperoleh dari BPS Statistik Indonesia dan Islamic Development Bank (ISDB)

\section{Jenis dan Sumber Data}

Penelitian ini memakai jenis data sekunder dengan pendekatan data runtut waktu (time series) dimulai dari tahun 1996 sampai 2018.

Sedangkan sumber data diperoleh dari instansi terkait atau pusat data secara online Badan pusat Statistik (BPS) dan Islamic Development Bank (ISDB).

\section{Definisi Operasionalisasi Variabel}

Berdasarkan rumusan hipotesis penelitian, mka definisi operasional variabel adalah :

1. Cadangan Devisa (Y)

Adalah seluruh peneriman dari aktiva luar negeri yang di kelola otoritas moneter dan dapat dipakai setiap waktu. Cadangan Devisa diukur dalam Satuan milyar US\$.

2. Ekspor (X1)

Ekspor merupakan proses pengiriman barang atau penjualan dari dalam negeri menuju luar negeri. Ekspor dalam penelitian ini diukur dengan Juta US\$.

3. Impor (X2)

Impor merupakan proses pengiriman barang dagangan dari luar negeri menuju wilayah Indonesia. Impor dalam penelitian ini diukur dengan satuan juta US\$.

\section{Hipotesis}




\section{Regresi Linear Berganda}

Analisis regresi merupakan analisis yang bertujuan untuk mengukur kekuatan dari hubungan satu atau lebih varibel bebas terhadap variabel terikat. Dalam mengalisis data penulis menggunakan metode analisis regresi linear berganda dengan program eviews 10 Adapun persamaan dari regresi linear berganda adalah sebagai berikut:

$$
\begin{aligned}
& \mathrm{LnY}=\beta 0+\beta 1 \mathrm{Ln} \mathrm{X} 1+\beta 2 \mathrm{Ln} \mathrm{X} 2+\mathrm{e} \\
& \text { Keterangan : } \\
& \mathrm{Y} \quad=\text { Cadangan Devisa (variabel terikat) } \\
& \beta 0=\text { Konstanta } \\
& \beta 1 \beta 2=\text { Koefisien masing-masing variabel } \\
& \mathrm{X} 1 \quad=\text { Ekspor minyak mentah } \\
& \mathrm{X} 2=\text { Impor minyak mentah } \\
& \mathrm{e} \quad=\text { Error trem (faktor pengganggu) } \\
& \mathrm{ln}=\text { Logaritma Natural: }
\end{aligned}
$$

\section{Uji Asumsi Klasik \\ Uji Normalitas}

Menurut (Ghozali, 2012) uji normalitas untuk mengetahui pada model regresi apakah data berdistribusi normal atau tidak. Penelitian ini menggunakan Jarque-Bera (J-B) test untuk mengetahui normal atau tidaknya model regresi, Dengan membandngkan nilai J-B hitung dengan nilai $\mathrm{C}^{2}$ (Chi-Square) tabel. Apabila nilai $\mathrm{J}-\mathrm{B}$ > nilai $\mathrm{C}^{2}$ tabel, maka nilai residual terdistribusi dengan tidak normal dan apabila nilai J-B hitung $<$ nilai $\mathrm{C}^{2}$ tabel, maka niali residual terdistribusi secara normal. Pengujian ini dilakukan dengan program eviews 10 dengan membandingkan nilai probabilitas $(P$-Value $)$ dan tingkat singnifikan (alpa). Jika probabilitas singnifikan 0,05 maka nilai residual berdistribusi normal begitu pula sebaliknya.

\section{Uji Heteroskedastisitas}

(Ghozalii, 2012) menyatakan bahwa pengujian heteroskedastisitas bertujuan untuk mengetahui apakah pada model regresi terdapat ketidaksamaan dari varians residual pengamatan yang lain. Jika varianss residual satu pengamatan kepengamatan yang lain konstan maka disebut homoskedstisitas namun jika berbeda disebut heteroskedastisitas. Cara mengetahui ada atau tidaknya heteroskedastisitas pada model regresi berganda yaitu dengan membandingkan nilai probabilitas obs*R-Square dan singnifikan (alpa) $5 \%$. Jika nilai probabilitasnya lebih tinggi dari 0,05 maka dapat disimpulakan tidak terjadi heteroskedastisitas, begitu pula sebaliknya

\section{Uji Autokolerasi}

Uji autokorelasi bertujuan untuk menguji dalam suatu model ada atau tidaknya korelasi antara kesalahan pengganggu pada periode $t$ dengan kesalahan pada periode t-1. (Ghozali, 2012) Menurut (Ghozali, 2012) apabila nilai Obs*RSquare < X2 (chi-square), maka tidak terjadi autokorelasi. Selanjutnya hasil uji autokorelasi juga dapat di lihat dengan membandingkan probabilitas Chi-Squared dan nilai signifikan 5\% apabila nilai Prob Chi-Squared > 5\%, maka ada terjadi autokorelasi.

\section{Uji Multikolenieritas}

Uji ini bertujuan untuk mengetahui suatu model apakah ada ditemukan kolerasi antara variabel independen atau variabel bebas (Ghozali, 2012). Untuk mengetahui dalam model terdapat multiko atau tidak yaitu dengan cara mengalisis matrik kolerasi variabel-variabel bebas. Jika antar variavel bebas tersebut ada kolerasi dengan nilai cukup tinggi (umumnya di atas 0,90) maka dalam model terjadi multikolenieritas (Ghozali, 2012)

\section{Pengujian Hipotesis}

Uji Parsial (uji t)

Pengujian ini dilakukan berdasarkan perbandingan nilai $t_{\text {hitung }}$ masing-masing koefisien regresi dengan nilai $t_{\text {tabel }}$ (nilai kritis) dengan tingkat signifikan 5\% dengan derajat kebebasan df $=(\mathrm{n}-\mathrm{k})$, dimana $\mathrm{n}$ adalah jumlah observasi dan $\mathrm{k}$ adalah jumlah variabel.

1. Jika $t_{\text {hitung }}<t_{\text {tabel }}(n-k)$, maka secara individu variabel independent (tidak berpengaruh terhadap variabel dependent.

2. Jika $t_{\text {hitung }}>\mathrm{t}_{\text {tabel }}(\mathrm{n}-\mathrm{k})$, maka secara parsial variabel independent berpengaruh terhadap variabel dependent

\section{Uji Simultan (uji f)}

Uji Simultan (Uji F) digunakan untuk menguji besarnya pengaruh dari seluruh variabel independent secara simultan tehadap variabel dependent. Untuk mendapatkan nilai $\mathrm{F}_{\text {tabel }}$, tingkat signifikan yang digunakan sebesar 5\% dengan derajat kebebasan (degree of freedom) df $=(n-k)$ dan (k-1) dimana $\mathrm{n}$ adalah jumlah observasi, kriteria uji yang digunakan adalah:

1. Apabila $F_{\text {hitung }}<F_{\text {tabel }}(k-1, n-k)$, maka secara simultan variabel independenttidak berpengaruh terhadap variabel dependent.

2. Apabila $F_{\text {hitung }}>F_{\text {tabel }}(k-1, n-k)$, maka secara simultan variabel independent berpengaruh terhadap variabel dependent 


\section{Koefisien Determinasi $\left(\mathbf{R}^{\mathbf{2}}\right)$}

Koefisien determinasi bertujuan untuk mengukur seberapa jauh kemampuan model dapat menjelaskan variasi variabel dependen. Dalam pengujian hipotesis pertama koefisien determinasi dilihat dari besarnya Ajudted $\mathrm{R}$ Square untuk mengetahui seberapa jauh variabel bebas terhadap variabel terikat. R2 mempunyai nilai berkisar 0 hingga $1(0 \leq \mathrm{R} 2 \leq 1)$. Jika nilai $\mathrm{R} 2$ bernilai besar (mendekati 1) artinya variabel bebas dapat memberikan penjelasan hampir sempurna yang dibutuhkan untuk menjelaskan variabel dependen. Sedangkan R2 bernilai kecil berarti kemampuan variabel bebas dalam memaparkan variabel dependen sangat terbatas (Ghozali, 2012)

\section{Koefisien Korelasi (R)}

Koefisien Korelasi bertujuan untuk mengetahui seberapa besar tingkat keeratan atau kekuatan hubungan antara variabel independen dengan variabel dependen (Y). Menurut (Sugiyono, 2012) berkisar antara -1 sampai dengan +1 yang criteria pemanfaatannya di jelaskan sebagai berikut:

1. Apabila nilai $\mathrm{R}>0$, artinya terdapat hubungan positif, yaitu semakin besar variabel $\mathrm{X}$ maka semakin besar variabel $\mathrm{Y}$

2. Apabila nilai $\mathrm{R}<0$, artinya telah terjadi hubungan yang negative, yaitu semakin kecil nilai variabel $X$ maka semakin besar variabel $\mathrm{Y}$ atau sebaliknya semakin besar variabel $\mathrm{C}$ maka semakin kecil variabel $\mathrm{Y}$.

3. Apabila nilai $\mathrm{R}=0$, artinya tidak ada hubungan sama sekali antara variabel $\mathrm{X}$ dengan variabel $\mathrm{Y}$.

4. Apabila nilai $\mathrm{R}=1$ atau $\mathrm{R}=-1$, artinya telah terjadi hubungan seempurna berupa garis lurus, sedangkan bagi $\mathrm{R}$ yang mengarah kearah angka 0 maka semakin tidak lurus.

\section{Hasil Penelitiian dan Pembahasan}

\section{Hasiil Uji Asumsi Klasik Hasil Uji Normalitas}

Berikut adalah hasil yang diperoleh dari program Eviews 9 yaitu :

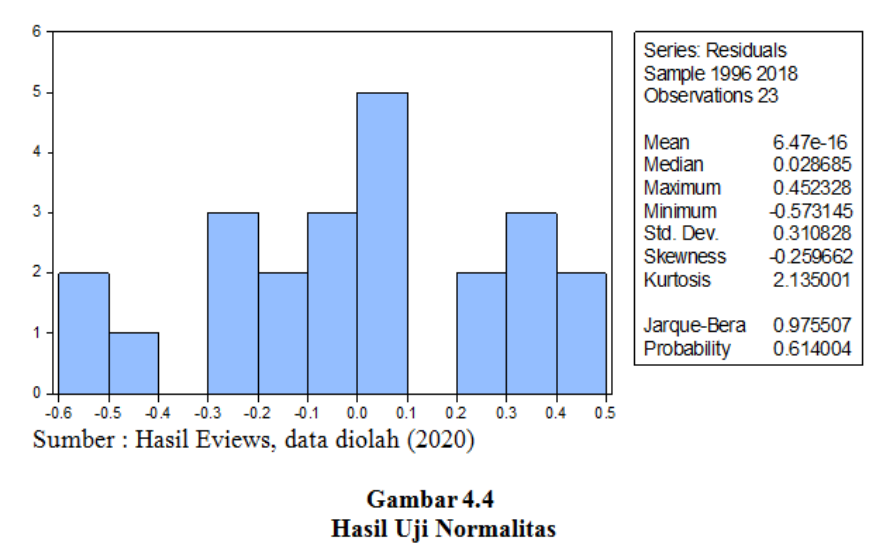

Hasil pengujian normalitas dalam penelitian ini diperoleh nilai jarque-beraa sebesar 0.97 dengan probabilitas $0.61>0,05$ maka disimpulkan data dalam penelitian telah terdistribusi dengan normal.

\section{Hasil Uji Heteroskedastisitas}

Hasil pengujian heteroskedastsitas yang didapat yaitu :

Tabel 4.1

Hasil Uji Heteroskedastisitas

Heteroskedasticity Test: White

\begin{tabular}{cccc}
\hline \hline F-statistic & 1.173689 & Prob. F(2,20) & 0.3296 \\
Obs*R-squared & 2.415929 & Prob. Chi-Square(2) & 0.2988 \\
Scaled explained SS & 1.036704 & Prob. Chi-Square(2) & 0.5955 \\
\hline
\end{tabular}

Sumber : Data dioleh, 2020

Dari hasli di atas dapat dilihat nilai obs* $\mathrm{R}$ square untuk hasil estimasi uji white adalah sebesar 2,41 dan nilai $\chi 2$ tabel dengan derajat kepercayaan $5 \%$ dan df (2) adalah 5,99 karena nilai Obs*Rsquared $(2,41<5,99)$ maka disimpulkan bahwa model diatas lolos dari heteroskedastisitas. Hal ini juga dapat dilihat dari probabilitas Chi-Squared sebesar 0,298>0,05.

\section{Hasil Uji Autokorelasi}

Berikut adalah hasil pengujian autokolerasi yang diperoleh dalam penelitian ini yaitu :

Tabel 4.2

Hasil Uji Autokorelasi

Breusch-Godfrey Serial Correlation LM Test:

\begin{tabular}{lccc}
\hline \hline F-statistic & 0.498466 & Prob. F(2,25) & 0.6161 \\
Obs*R-squared & 1.218680 & Prob. Chi-Square(2) & 0.5437 \\
\hline \hline
\end{tabular}

Sumber: Data diolah (2020)

Berdasarkan hasil out put Obs * R-squared sebesar 1,21 di bandingkan dengan Chi-Squared tabel pada df (2) sebesar 5,99, maka 1,21 < 5,99 berarti tidak terjadi autokorelasi dalam penelitian. Hal ini juga dapat dilihat dari Pro. Chi Square lebih tinggi dari 0,05 yaitu 0,543 . 


\section{Hasil Uji Multikolinieritas}

Tabel 4.3

Hasil Uji Multikolinieritas

\begin{tabular}{|c|c|c|c|}
\hline & $\begin{array}{c}\text { Cadangan__ } \\
\text { Devisa }\end{array}$ & $\begin{array}{c}\text { Ekspor_Minyak } \\
\text { Mentah }\end{array}$ & $\begin{array}{c}\text { Impor_Minyak } \\
\text { Mentah }\end{array}$ \\
\hline Cadangan_Devisa & 1 & 0.4271 & 0.7796 \\
\hline Ekspor_Minyak_Mentah & 0.4271 & 1 & 0.7682 \\
\hline Impor_Minyak_Mentah & 0.7796 & 0.7682 & 1 \\
\hline
\end{tabular}

Sumber : Hasil eviews, 2020

Berdasarkan Tabel 4.3 di atas menunjukkan bhawa hasil penelitian ini tidak ada hubungan korelaasi antar variabel dalam penelitian atau tidak ada multikoliniritas, hal ini dibuktikan oleh nilai korelasi tiap-tiap variabel di bawah 0,90 , dimana ekspor minyak mentah mempunyai nilai korelasi sebesar $0,4<0,90$ dan impor minyak mentah mempunyai nilai korelasi $0,7<0,90$.

\section{Analisis Regresi Linier Berganda}

Hasil pengujian dalam pnelitian ini yaitu :

Tabel 4.4

Hasil Analisis Regresi Linier Berganda

Dependent Variable: LOG(CADANGAN_DEVISA)

Method: Least Squares

Sample: 19962018

Included observations: 23

\begin{tabular}{lrrrr}
\hline \hline \multicolumn{1}{c}{ Variable } & Coefficient & Std. Error & t-Statistic & Prob. \\
\hline \hline \multicolumn{1}{c}{ C } & 8.173025 & 1.863034 & 4.386943 & 0.0003 \\
Log(Ekspor_Minyak_Mentah) & -0.648873 & 0.293085 & -2.213942 & 0.0386 \\
Log(Impor_Minyak_Mentah) & 0.980471 & 0.138254 & 7.091812 & 0.0000 \\
\hline \hline R-squared & 0.787400 & & & \\
Adjusted R-squared & 0.766140 & & & \\
F-statistic & 37.03674 & & & \\
Prob(F-statistic) & 0.000000 & & & \\
\hline \hline
\end{tabular}

Sumber : Eviews 9, data diolah (2020)

Hasil estimasi dengan memasukkan rumus maka diperoleh:

\section{LnX2}

$\operatorname{LnY}=8,173025-0,648873 \operatorname{LnX} 1+0,980471$

Dari hasil diatas dapat di interpretasi hasil yaitu :

Constanta sebesar 8,173025 menunjukkan apabila ekspor minyak mentah $\left(\mathrm{X}_{1}\right)$, dan impor minyak mentah $\left(\mathrm{X}_{2}\right)$ bernilai konstan maka cadangan devisa (Y) bernilai sebesar 8,173025 $\%$.

Koefisien variabel ekspor minyak mentah $\left(\mathrm{X}_{1}\right)$ mempunyai nilai negatif sebesar - 0,648873. Artinya apabila ekspor minyak mentah $\left(\mathrm{X}_{1}\right)$ meningkat $1 \%$ maka cadangan devisa (Y) akan berkurang sebesar $0,648873 \%$ dengan asumsi impor minyak mentah bernilai konstan.
Koefisien variabel impor minyak mentah $\left(\mathrm{X}_{2}\right)$ mempunyai nilai positif sebesar 0,980471 . Artinya apabila impor minyak mentah $\left(\mathrm{X}_{2}\right)$ meningkat $1 \%$ maka cadangan devisa (Y) akan meningkat sebesar $0,980471 \%$ dengan asumsi ekspor minyak mentah bernilai konstan

\section{Hasil Pengujian Hipotesis \\ Hasil Uji Parsial (Uji t)}

dilakukan dengan membandingkan nilai t hitung dengan $\mathrm{t}$ tabel dengan cara df $(\mathrm{n}-\mathrm{k})=(23-3)=20$ pada $\alpha 5 \%$ dan $1 \%$ adalah sebesar 2,085 dan 2,845, maka diperoleh hasil yaitu :

Variabel ekpsor minyak mentah $\left(\mathrm{X}_{1}\right)$ berpengaruh secara signifikan dan negatif terhadap variabel cadangan devisa (Y). Hal ini didasarkan pada nilai $\mathrm{t}_{\text {hitung }}>\mathrm{t}_{\text {tabel }}$ yakni $-2,213>2,085$ maka terima $\mathrm{H}_{1}$. Hal ini juga bisa dilihat dari probabilitas $(\mathrm{p}-$ value) sebesar $0.03<0.5$.

Variabel impor minyak mentah $\left(\mathrm{X}_{2}\right)$ berpengaruh secara signifikan dan positif terhadap variabel cadangan devisa (Y). Hal ini didasarkan pada nilai $\mathrm{t}_{\text {hitung }}>\mathrm{t}_{\text {tabel }}$ yakni 7,091 > 2,845 maka terima $\mathrm{H}_{2}$. Hal ini juga bisa dilihat dari probabilitas $(\mathrm{p}-$ value) sebesar $0.000<0.01$.

\section{Hasil Uji Simultan (Uji f)}

Berdasarkan hasil pengujian pada tabel 4.4 di atas maka dapat dilihat bahwa nilai $F_{\text {hitung }}$ sebesar 37.036 dengan Prob sebesar 0,000, sedangkan $\mathrm{f}_{\text {tabel }}$ pada $\mathrm{df}=(\mathrm{k}-1)(\mathrm{n}-\mathrm{k})=(3-1)(23-3)=(2)(20)$ yaitu sebesar 3,490 dari $\alpha=1 \%$, maka $F_{\text {hitung }}>F_{\text {tabel }}$ yaitu 37,036 > 3,490. Maka disimpulkan $\mathrm{H}_{3}$ diterima artinya secara simultan ekspor minyak mentah dan impor minyak mentah berpengaruh signifikan dan positif terhadap cadangan devisa (Y).

\section{Hasil Koefisien Determiinasi $\left(\mathbf{R}^{\mathbf{2}}\right)$}

Berdasarkan Tabel 4.4 diatas hasil uji Koefisen determinasi $\mathrm{R}^{2}$ di lihat dari nilai Ajudted $R$ Square yaitu sebesar 0,7661 Maka besarnya pengaruh variabel ekspor minyak mentah dan impor minyak mentah terhadap cdangan devisa tahun 1996-2018 adalah sebesar 76,61 \%. Sedangkan sisanya di pengaruhi oleh variabel lain diluar model yaitu $23,39 \%$.

\section{Hasil Koefisien Kolerasi (R)}

Hasil yang diperoleh dari nilai $\mathrm{R}=\sqrt{R^{2}}=$ $\sqrt{0,7661}=0,8752$. Maka dapat disimpulkan hubungan antara ekspor minyak mentah dan impor minyak mentah terhadap cadangan devisa tahun 1996-2018 berpengaruh sangat kuat secara positif, 
karena nilai korelasi sebesar 87,52 Persen hampir medekati positif satu.

\section{Pembahasan \\ Pengaruh Ekspor Minyak Mentah Terhadap Cadangan Devisa}

Hasil penelitian menjelaskan bahwa ekpsor minyak mentah berpengaruh negative terhadap cadangan devisa. Hal ini menunjukkan bahwa semakin tinggi ekspor minyak mentah maka akan mengurangi cadangan devisa. Hasil penelitian ini menggambarkan Indonesia semakin mengalami penurunan dalam produksi minyak mentah sehingga ekspor minyak mentah setiap tahun juga berkurang. Namun penurunan ekspor minyak mentah tidak menyebabkan menurunnya cadangan devisa, hal ini dikarenakan tingginya ekspor komoditas lain yang meningkatkan cadangan devisa.

Hasil penelitian ini seusai dengan pendapat (Febriyenti, 2013) bahwa meningkatnya ekspor di Indonesia akan mengurangi cadangan devisa. Hal ini terjadi karena peningkatan perekonomian luar negeri lebih tinggii daripada peningkatan perekonomian Indonesia sehingga nilai mata uang asing lebiih besar di bandingkan nilai tukar rupiah, akibatnya neraca pembayran yang diterima Indonesia akan semakin rendah dan berdampak pada menurunnya cadangan devisa.

Hasil penelitian ini sejalan dengan penelitian (Uli, 2016) yang menyimpulkan bahwa ekspor berpengaruh negatif terhadap cadangaan devisa. Hasil penelitian ini pun mendukung penelitian yang dilakukan oleh (Putra \& Damanik, 2017) yang menjelaskan bahwa ekspor berpengaruh negatif terhadap cadangan devisa. Menurut (Putra \& Damanik, 2017) adanya hasil yang negatif pengaruh ekspor maka diperlukan suatu pembinaan yang lebih terfokus dalam memperluas pasar dari produk menjadi produk non migas Indonesia agar dapat meningkatkan daya saing agar mencapai kesejahteraan bagi kelangsungan hidup dan juga dapat membantu dalam memperbaiki cadangan devisa.

Namun hasil penelitian ini tidak sejalan dengan penelitian (Benny, 2013) dan (Reny \& Agustina, 2014) yang menyimpulkan ekspor mempunyai pengaruh positif dan signifikan bagi cadangan devisa di Indonesia.

\section{Pengaruh Impor Minyak Mentah Terhadap Cadangan Devisa}

Hasil penelitian menunjukkan bahwa Impor minyak mentah berpengaruh positif terhadaap cadangan devisa. Hal ini menunjukkan bahwa semakin meningkat impor minyak mentah maka cdangan devisa juga akan meningkat. Dalam melakukan impor maka pemerintah membayar dengan menggunakan devisa, sehingga apabila impor yang dilakukan tinggi akan mengurangi persediaan devisa negara.

Akan tetapi tingginya impor didorong dari kuatnya permintaan dalam negeri terhadap barang impor tersebut, kemudian bahan baku di Indonesia harga dan biaya tenaga kerja yang murah membuat investor tertarik berinvestasi modalnya untuk membangun pabrik, sehingga alirandana modalaasing yang masuk akan mengakibatkan meningkat neraca perdagangan indonesia dan cadangan devisa juga meningkat (Agustina, 2014).

Hasil penelitian ini searah dengan penelitian (Agustina, 2014) dan (Mustika et alth, 2015) yang menyimpulkan bahwa impor mempunyai pengaruh positif bagi cadangan devisa. Hubungan impor dengan cadangan devisa yaitu karena impor didanai olehdevisa, sehingga mampu dan sangggup dalam menghasilkan barang-barang yang bersaing dengan barang luar negeri sangatlah penting. Selanjutnya perusahaan yang mengimpor suatu barang akan membutuhkan jumlah devisa yang banyak untuk membayar transaksi tersebut. Sehingga ketersedian cadangan devisa akan memegang perenan penting dalam kegiatan impor, mengingat jika sebuah negara akan melakukan impor padasaat tidak mampu diproduksi dalam negeri, maka dengan terhambatnya kegiatan impor maka ikut terhambat pula kegiatandalam negeri.

Hasil penelitian ini bertolak belakang dengan penelitian (Benny, 2013) yang menyimpulkan bahwa impor berpengaruh negatif terhadap cadangan devisa. Sementara itu, (Agustina, 2014) menyataan bahwa dalam hasil penelitianya impor tidak berpengaruh terhadap cadangan devisa.

Hasil penelitian yang positif juga disebabkan karena PT Pertamina (Persero) belum bisa meneruskan pembangunan kilang baru di Bontang. Padahal, adanya kilang minyak sangat diperlukan Indonesia dapat mengurangi impor minyak yang berpengaruh besar ke defisit neraca perdagangan. Keputusan tersebut diambil setelah kerja sama dengan mitra terhenti. 


\section{PENUTUP}

\section{Kesimpulan}

Berdasarkan hasil penelitian maka diperoleh kesimpulan sebagai berikut :

1. Secara parsial ekpsor minyak mentah berpengaruh negatif dan signifikan trhadap variabel cadangan devisa.

2. Secara parsial impor minyak mentah berpengaruh positif dan signifikan terhadap variabel cadangan devisa.

3. Secara simultan ekspor minyak mentah dan impor minyak mentah berpengaruh signifikan dan positif terhadap cadangan devisa di Indonesia.

\section{Saran}

Adapun saran yang dapat diberikan peneliti dalam penelitian ini adalah sebagai berikut :

1. Bank Indonesia sebagai pihak yang harus menjaga keseimbangan cadangan devisa. Karena cadangan devisa merupakan indikator kekuatan perekonomian suatu negara serta kemampuan suatu negara dalam melakukan pembiayaan perdagangan internasional. Perdagangan internasional (ekspor-impor) merupakan penyumbang hasil yang besar bagi cadangan devisa Indonesia.

2. Bagi pihak Eksportir dan Importir. Diharapkan Indonesia mampu meningkatkan, pemerintah dapat memberikan kebijakankebijakan kepada masyarakat khususnya yang akan melakukan ekspor, agar mendapat kemudahan dalam memenuhi syarat melakukan ekspor serta Pemerintah harus menekan pertumbuhan impor.

3. Diharapkan Pemerintah melakukan kebijakan substitusi impor dengan mengganti komoditi yang selalu diimpor. Langkah yang dapat diambil adalah mendorong ekspor dan membangun industri dalam negeri lebih bekembang sehingga tidak terlalu banyak mengimpor.

4. Ekspor Migas Indonesia, perlu adanya suatu kajian yang lebih khusus agar dapat menjaga kelangsungan sumber daya alam sekaligus diperlukan suatu produk derivatif dengan hasil olahan yang lebih kreatif dan inovatif untuk meningkatkan kinerja ekspor non migas.
5. Bagi penelitian selanjutnya, peneliti dapat menambahkan variable variabel lain yang belum diteliti untuk bisa ditambahkan untuk menambah khasanah penelitian.

\section{DAFTAR PUSTAKA}

Agustina, R. (2014). Pengaruh ekspor, impor, nilai tukar rupiah, dan tingkat inflasi terhadap cadangan devisa indonesia. Jurnal Wira Ekonomi Mikroskil, 04(02), 61-70.

Amir, M. S. (2004). Strategi Memasuki Pasar Ekspor. Jakarta: Victory Jaya Abadi.

Amir, M. S. (2008). Handbook of Export Import Business. Jakarta: Victory Jaya Abadi.

Atty, D., Zulkifli, M., Muhammad, H., Hamzah, Z., \& Trijana, R. S. (2013). Economy Growth and Oil Import Requirement in Indonesia. 3(11), 76-84.

Benny, J. (2013). Ekspor Dan Impor Pengaruhnya Terhadap Posisi Cadangan Devisa Di Indonesia. Jurnal Riset Ekonomi, Manajemen, Bisnis Dan Akuntansi, 1(4), 1406-1415.

Devi, \& Andriyani, M. (2020). Pengaruh Ekspor Impor kakao dan karet Terhadap Cadangan Devisa Di Indonesia. Ekonomi Pertanian Universitas Malikussaleh, 03(November), 34. https://doi.org/10.47498/tasyri.v12i2.384

Dewi, M. A. J. K., \& Sudirman, I. W. (2015). Analisis Faktor-Faktor yang Mempengaruhi Impor Minyak Bumi di Indonesia Tahun 19962015. E-Jurnal EP Unud, 6(7), 1364-1394.

Ekanada. (2014). ekonomi internasional. \{Penerbit Erlangga.

Febriyenti, M. (2013). FAKTOR-FAKTOR YANG MEMPENGARUHI CADANGAN DEVISA DAN NET EKSPOR DI INDONESIA Oleh: Mega Febriyenti, Hasdi Aimon, Zul Azhar. Jurnal Kajian Ekonomi, 2(1), 156-171.

Feriyanto, A. (2015). Perdagangan Internasional. Yogyakarta, Pustaka Baru Press.

Ghozali, I. (2012). Aplikasi Multivariate Dengan Program spss. Semarang Badan penerbit Universitas Diponegoro.

Juniantara, I., \& Sri Budhi, M. (2012). Pengaruh Ekspor, Impor dan Kurs Terhadap Cadangan Devisa Nasional Periode 1999-2010. E-Jurnal Ekonomi Pembangunan Universitas Udayana, 1(1), 32-38.

Leonufna, L., Kumaat, R., Mandeij, D., \& Ratulangi, U. S. (2016). INTERNASIONAL TERHADAP TINGKAT KURS RUPIAH / DOLLAR AS MELALUI CADANGAN DEVISA DALAM SISTEM KURS MENGAMBANG BEBAS DI INDONESIA EXCHANGE RATE 
RUPIAH AGAINST US DOLLAR

THROUGH FOREIGN EXCHANGE

RESERVES UNDER FREE FLOATING

EXCHANGE RATE SYSTEM IN. 16(02),

315-324.

Mustika, Haryadi, \& Siti Hodijah. (2015).

Pengaruh Ekspor dan Impor Minyak Bumi terhadap Pertumbuhan Ekonomi Indonesia .

Jurnal Perspektif Pembiayaan Dan

Pembangunan Daerah, 2(3), 107-118.

Prambudia, Y. \& M. N. (2012). Exploring Malaysia's transformation to Net Oil Importer and Oil Import Dependence. Ekonomi, 04.

Putra, M. U. M., \& Damanik, S. (2017). Pengaruh Ekspor Migas Dan Non Migas Terhadap Cadangan Devisa Di Indonesia. Jurnal Wira Ekonomi Mikroskil, 7(2), 245254.

Reny, \& Agustina. (2014). Pengaruh Ekspor, Impor, Nilai Tukar Rupiah, Dan Tingkat Inflasi Terhadap Cadangan Devisa Indonesia. Jurnal Wira Ekonomi Mikroskil, 4(2), 61-70.

Ridho, M. (2015). Pengaruh Inflasi, Kurs Rupiah, Utang Luar Negeri Dan Ekspor Terhadap Cadangan Devisa Indonesia. E-Jurnal Perdagangan, Industri Dan Moneter, 3(1), $1-25$.

Sabtiadi, K., \& Kartikasari, D. (2018). Analisis Pengaruh Ekspor Impor Terhadap Nilai Tukar Usd Dan Sgd. JURNAL AKUNTANSI, EKONOMI Dan MANAJEMEN BISNIS, 6(2), 135-141. https://doi.org/10.30871/jaemb.v6i2.629

Safitri, H., Disty, A. A., Sumah, N. M., \& Zulaehah, A. (2014). Analisis Neraca Perdagangan Migas Dan Non Migas Indonesia Terhadap Volatilitas Cadangan Devisa 2003-2013. Economics Development Analysis Journal, 3(2), 353-361. https://doi.org/10.15294/edaj.v3i2.3843

Sasono, H. . (2013). Manajemen Ekspor dan Perdagangan Internasional. Yogyakarta: Andi Offset.

Soi, N., Koskei, I., Buigut, K., \& Kibet, J. (2013). Effect of International Trade on Economic Growth In Kenya. 5(10), 131-138.

Sonia, A. P., \& Setiawina, N. D. (2016). PENGARUH KURS , JUB DAN TINGKAT INFLASI TERHADAP EKSPOR, IMPOR DAN CADANGAN DEVISA INDONESIA. E-Jurnal EKonomi Pembangunan, 05(10), 1077-1102.

Sonia, A., \& Setiawina, N. (2016). Pengaruh
Kurs, Jub Dan Tingkat Inflasi Terhadap Ekspor, Impor Dan Cadangan Devisa Indonesia. E-Jurnal Ekonomi Pembangunan Universitas Udayana, 5(10), 1077-1102.

Sukirno, S. (2005). Makro Ekonomi Modern. PT. Raja Grafindo Persada. Jakarta.

Tambunan T. (2001). Perdagangan Internasional Dan Neraca Pembayaran. Boogor(ID): Ghalia Indonesia.

Uli, L. B. (2016). Analisis Cadangan Devisa Indonesia. Jurnal Perspektif Pembiayaan Dan Pembangunan Daerah, 4(1), 15-24.

Wahyuni, S. (2011). Analisis Faktor-faktor yang mempengaruhi Cadangan Devisa Indonesia periode 2001-2010. Universitas Udayana. 